\title{
10 W High Efficiency 14V HBT Power Amplifier for Space Applications
}

\author{
N. LE GALLOU* , J.F.VILLEMAZET* ,B. COGO*, J.L CAZAUX*, \\ A. MALLET**, L. LAPIERRE ** \\ * ALCATEL SPACE, 26 Av. JF Champollion, 31037 Toulouse cedex, FRANCE \\ ** CNES (French Space Agency), 18 Av. E. Belin 31401 Toulouse cedex 4, France \\ e-mail : Nicolas.Le-Gallou@space.alcatel.fr / Fax : +33 534356947 \\ http://www.alcatel.com/space
}

\begin{abstract}
This paper presents the first development of a space-borne power amplifier using the recently developed high breakdown, high Power HBT HB20S process of UMS. The inverse F class Hybrid Power Amplifier has been designed using intensive simulation methods developed at Alcatel Space for MMICs, allowing to reach very high performances without manual tuning. The results $10 \mathrm{~W} / \mathrm{PAE}>65 \%$ obtained with a single chip at $1.5 \mathrm{GHz}$ demonstrate the capability of the process to handle with very high power densities and efficiencies.
\end{abstract}

\section{I ) INTRODUCTION}

For the last few years, the GaInP/GaAs HBT power technology has become mature enough to be compatible with on board space applications [1]

Recent developments around a very high power HBT process (HB20S) at UMS [2] has given an intermediary short term schedule for the use of high breakdown voltage components before wide bandgap component industrial standardisation. The fundamental characteristics of this process are a Vce breakdown $=31 \mathrm{~V}$, and a $\mathrm{Vcb}$ breakdown $=$ $65 \mathrm{~V}$.

The application of such a very high power process in next upcoming spatial navigation programs like Galileo, which are very demanding on solid state high power amplifiers, could be of particular interest.

\section{II ) TOPOLOGY OF HBT DEVICES}

The devices used for this work are based on a fishbone type elementary cell of 16 fingers of $2 \times 70 \mu \mathrm{m}^{2}$ emitter area. The corresponding layout is given in Figure 1.

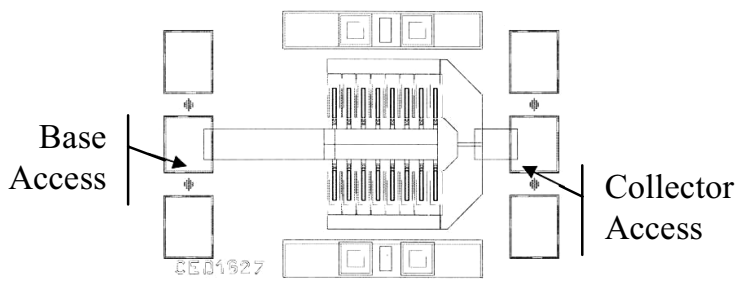

Figure 1 : Layout of a $16 \times\left(2 \times 70 \mu m^{2}\right)$ cell
The discrete power bar mounted in the hybrid circuit described in this paper, is composed of 4 elementary cells in parallel sharing an single $30 \mu \mathrm{m}$ thick thermal drain connected to emitter fingers at the upper side and joining the backside metal through via holes. In front of each elementary cell, a pre-matching circuit has been included directly on GaAs (Figure 2). The substrate thickness is $100 \mu \mathrm{m}$.

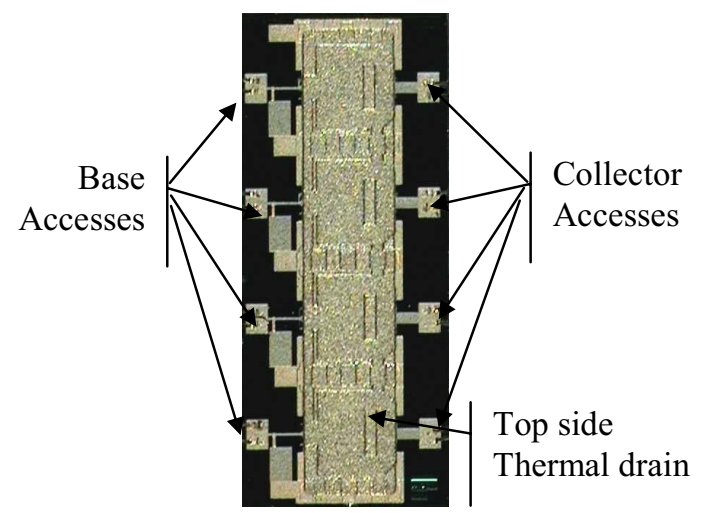

Figure 2 : Top side view of the Power chip

\section{III ) LOAD PULL AND DESIGN METHOD}

An electrothermal model of the $16 \times\left(2 \times 70 \mu \mathrm{m}^{2}\right)$ elementary cell has been extracted using pulsed I/V and $\mathrm{S}$ parameters, obtained for different base plate temperatures [3].

The bias point for an elementary cell has been chosen at $\mathrm{Vce}=14 \mathrm{~V} /$ Ice $=50 \mathrm{~mA}$, in deep AB class and not in $\mathrm{B}$ class to preserve small signal gain. The base is biased using a mix bias method including a series resistor and a voltage source.

Despite the possibility to bias at a voltage superior to $20 \mathrm{~V}$, the $14 \mathrm{~V}$ value has been chosen to limit junction temperature. The component is consequently used in a particularly safe area, particularly attractive for space applications.

The optimum load conditions have been determined for an optimum PAE using load and source pull simulations at fundamental frequency fo but also at second harmonic $2 \mathrm{f0}$. The optimum impedance found (Figure 3) show a remarkably high value at f0 (easier to match to $50 \Omega$ ) as a direct consequence of the high voltage collector bias point, and a quasi open circuit at $2 \mathrm{fO}$ leading to inverse $\mathrm{F}$ class [4]. 


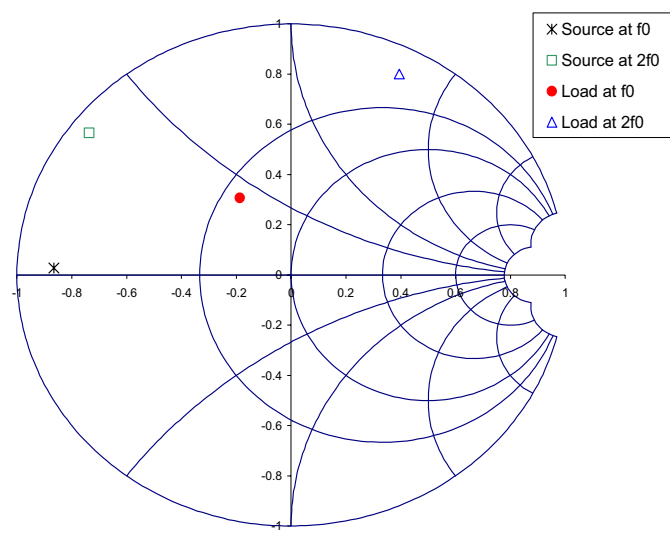

Figure 3 : Optimum Load / Source Impedance

Input and output matching circuits are made with a high dielectric constant material to minimise losses as well as dimensions.

The hybrid amplifier has been first simulated using standard equivalent elements of a commercial simulator microstrip library. Then, to overcome the library limitation for the high dielectric constants, a complete quasi 3D electromagnetic simulation [5] of the matching circuits has been performed.

The simulated non linear results given in Figure 4 show for $2 \mathrm{~dB}$ of gain compression over the frequency range $1.525 / 1.625 \mathrm{GHz}$ a module output Power $>10 \mathrm{~W}$, a module PAE $>62 \%$ (peak to $65 \%$ ) and an associated Gain $>13.2 \mathrm{~dB}$ (peak to $13.75 \mathrm{~dB}$ ). The resulting power density at $\mathrm{Vce}=14 \mathrm{~V}$ is $2.23 \mathrm{~W} / \mathrm{mm}$ corresponding to 6 times the power density of a typical HFET L band power amplifier $\lceil 6\rceil$.

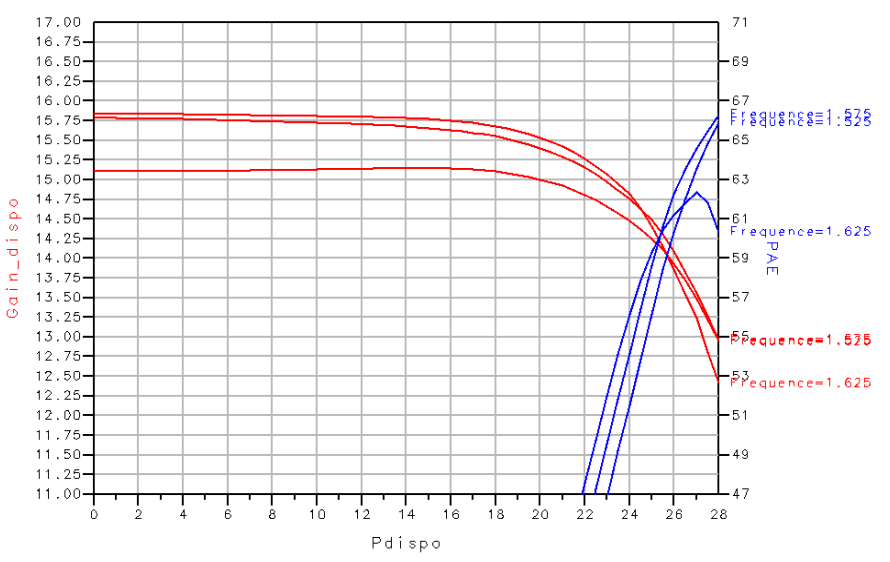

Figure 4 : Simulated performances

\section{IV ) TIME DOMAIN WAVEFORMS}

One of major concern for space application is the reliability of the equipment manufactured. For a power amplifier, the critical part is the transistor whose intrinsic (technological) reliability characteristics shall be satisfactory (typically MTTF $>10^{6}$ Hours). The time domain visualisation of voltage and current waveforms gives an evaluation of the dynamic stress applied to the component and shall respect the normalised derating (i.e. $75 \%$ ) of foundry maximum ratings. For the High breakdown voltage HB20S process, UMS gives the following static maximum ratings, for the collector to base breakdown voltage : $\mathrm{Vcb}_{\mathrm{B}}=65 \mathrm{~V}$, and for the collector to emitter breakdown voltage $\mathrm{Vce}_{\mathrm{B}}=31 \mathrm{~V}$.
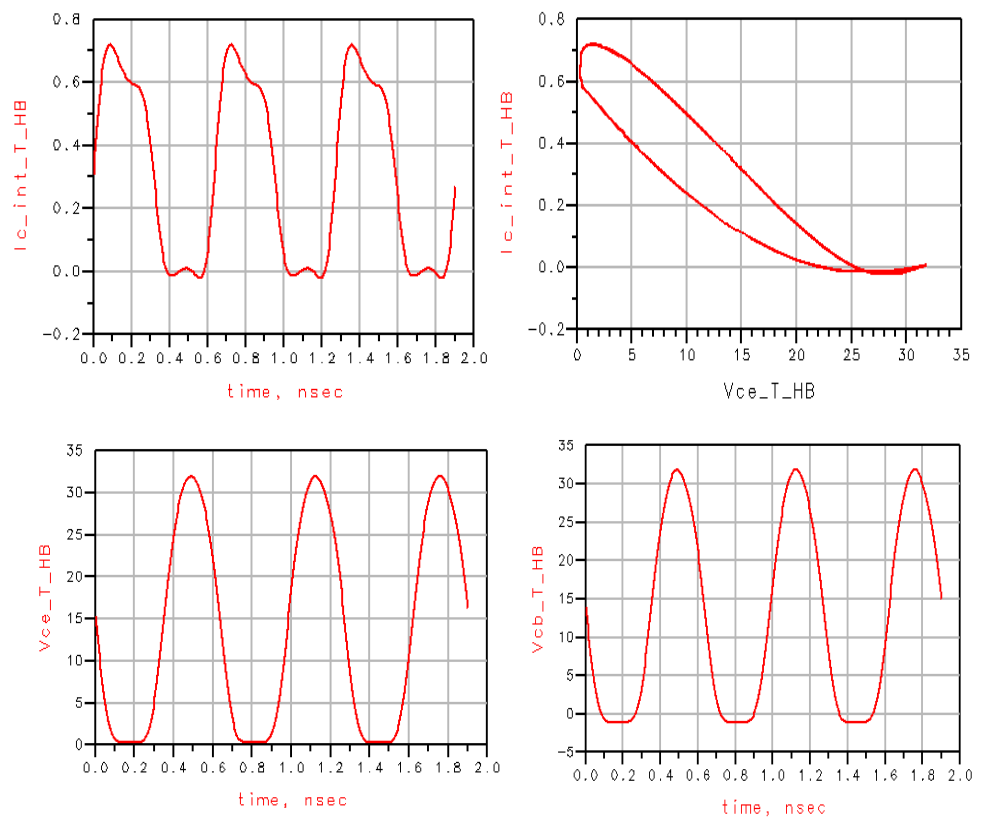

Figure 5: Load Pull Simulated Time Waveforms (P2dB)

As it is shown in Figure 5 (Load Pull simulated waveforms corresponding to $2 \mathrm{~dB}$ of HPA gain compression), the Vce dynamic voltage with a peak value of $31 \mathrm{~V}$ remains inferior to the static $\mathrm{Vce}_{\mathrm{B}}$ as well as for the $\mathrm{Vcb}$ waveform with an absolute peak to $33 \mathrm{~V}$ to compare with the $65 \mathrm{~V}$ of $\mathrm{Vcb}_{\mathrm{B}}$. This graphs show an important margin (better than the rated $25 \%$ ) to the most critical value $\mathrm{Vcb}_{\mathrm{B}}$ for reliability. The static Vce maximum rating is respected.

As a second comparison, the Figure 6 shows the same waveforms (for $2 \mathrm{~dB}$ of gain compression), at 3 frequencies (upper, center and lower in the bandwidth), simulated for the transistors with its matching networks inside the HPA. As it is shown the same margin versus $\mathrm{Vcb}_{\mathrm{B}}$ and $\mathrm{Vce}_{\mathrm{B}}$ are obtained.

\section{V ) RF CW POWER MEASUREMENTS}

The realised amplifier has been measured using $\mathrm{CW}$ signal in a slightly shifted band $(70 \mathrm{MHz})$ compared to simulations. The measurement results (Figure 7) show at least $10 \mathrm{~W}$ of output power for $2 \mathrm{~dB}$ of gain compression and an associated PAE $>64.5 \%$ (peak to $66 \%$ ) over $50 \mathrm{MHz}$ bandwidth for an associated Gain $>13 \mathrm{~dB}$ (peak to $13.6 \mathrm{~dB}$ ). The very good correlation between simulated and measured performances show the validity of the transistor model and design method. 

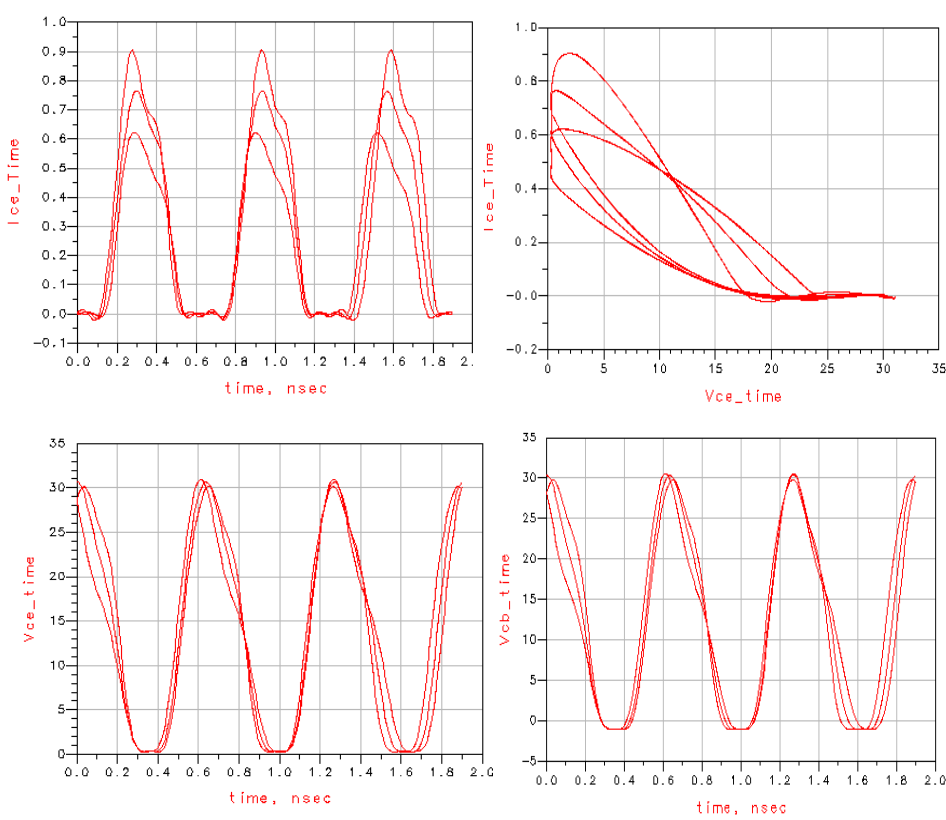

Figure 6: Designed HPA Simulated Time Waveforms (P2dB)

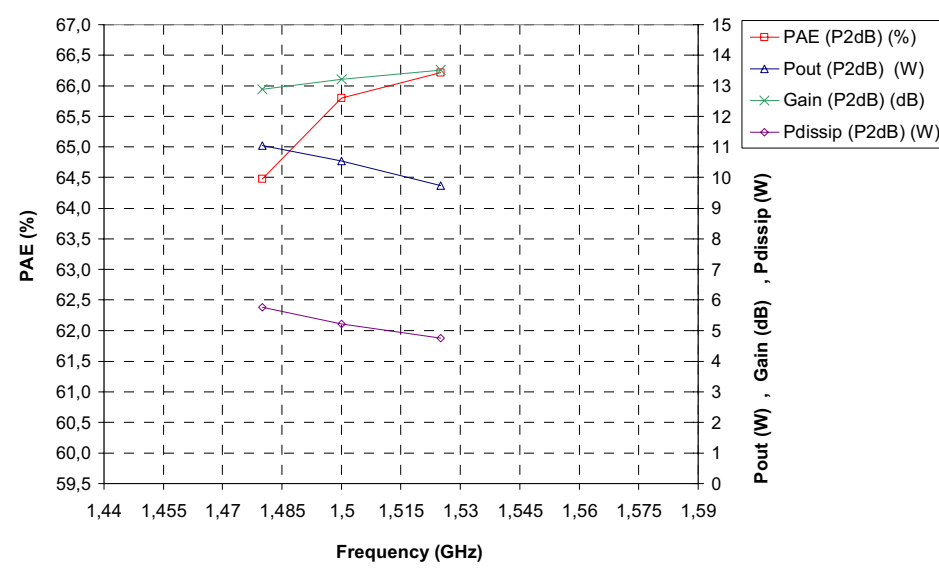

Figure 7 : CW Power module Measurements

These performances, reported between input and output plans of a $50 \Omega$ module (Figure 12) without any deembeding of the losses due to the test jig or SMA connectors, are, as far as we know, in the state art of the $10 \mathrm{~W}$ single chip category. Previous work on High Voltage Breakdown HBT reported $20 \mathrm{~W}$ and a PAE $=62 \%$ at a transistor level for a $28 \mathrm{~V}$ bias [7].

\section{VI) RF TWO TONE MEASUREMENTS}

Compared to the typical performances of a HFET module commonly used in space applications [6], the 2 Tone linearity of the high Voltage HBT power module shows a particular improvement especially for high compression zone. Typically as it is shown in the Table 1, the improvement compared to a HFET could be up to $4 \mathrm{~dB}$ for $\Delta \mathrm{f}=10 \mathrm{MHz}$ at $-3 \mathrm{~dB}$ of IBO (input power back off).

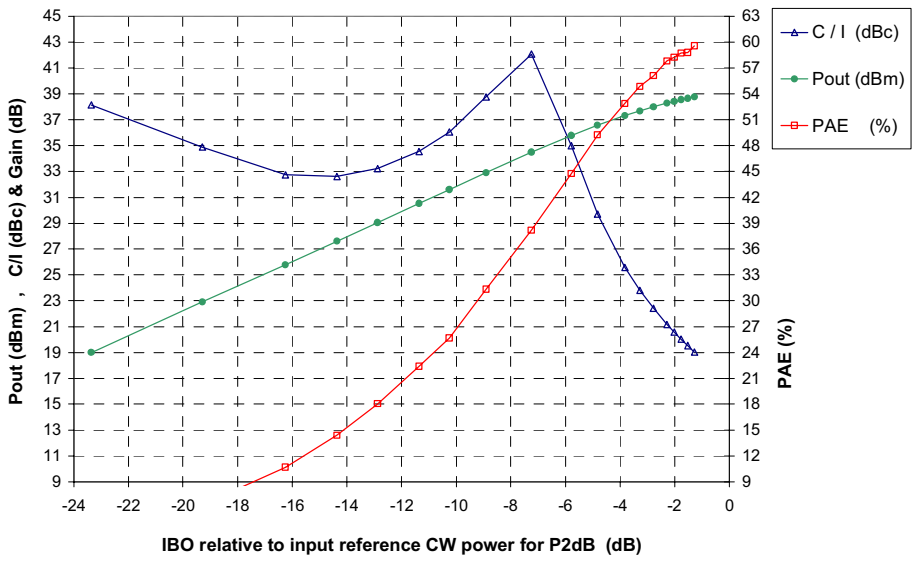

Figure 8 : 2 Tones Power module Measurement

\begin{tabular}{|c|c|c|}
\hline $\begin{array}{c}3^{\text {rd }} \text { order } \\
\text { intermod. }\end{array}$ & $\begin{array}{c}\text { HBT HB20S } \\
10 \mathrm{~W} \text { L Band }\end{array}$ & $\begin{array}{c}\text { HFET } \\
\text { C Band }\end{array}$ \\
\hline $\mathrm{IBO} / \mathrm{CW}$ & $\Delta \mathrm{f}=10 \mathrm{MHz}$ & $\Delta \mathrm{f}=10 \mathrm{MHz}$ \\
\hline$-3 \mathrm{~dB}$ & $23.2 \mathrm{dBc}$ & $19.1 \mathrm{dBc}$ \\
\hline$-10 \mathrm{~dB}$ & $36.7 \mathrm{dBc}$ & $35 \mathrm{dBc}$ \\
\hline$-17 \mathrm{~dB}$ & $33 \mathrm{dBc}$ & $44 \mathrm{dBc}$ \\
\hline
\end{tabular}

Table 1:Linearity as a function of Input BackOff

The reference input power for IBO is the input power for $2 \mathrm{~dB}$ of $\mathrm{CW}$ gain compression

\section{VII) JUNCTION TEMPERATURE}

The elementary cell and the whole packaging environment have been thermally simulated to estimate the thermal resistance as a function of base plate temperature. The graph presented in Figure 9 depicts the thermal distribution between each emitter finger (only half of the structure has been simulated for symmetry reasons). It is shown that the center fingers are the hottest, and depending on the position in the finger as well as the finger considered, the thermal gradient can reach $10^{\circ} \mathrm{C}$ (edge effect).

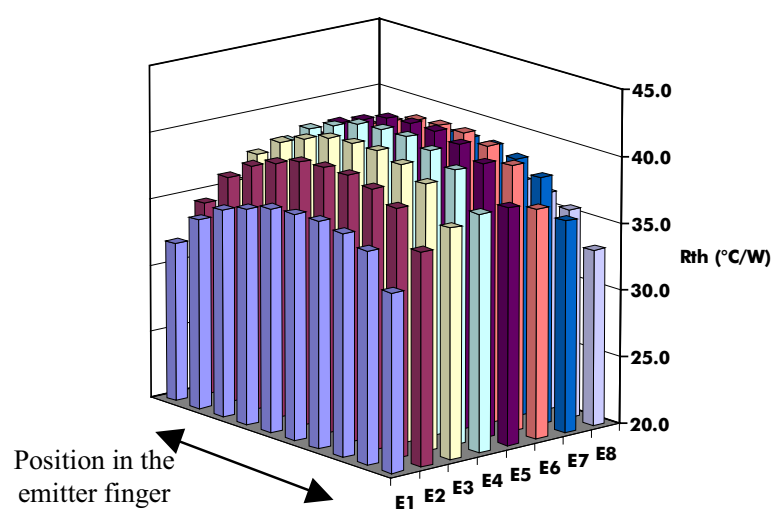
Figure 9 : Thermal distribution between 8 emitter
fingers of the elementary cell

On the basis of these results, the evolution of Rth has been plotted versus base plate temperature, taking into account the max temperature or the average temperature over an elementary cell. 
As it is shown in Figure 10, the thermal resistance of the elementary cell reaches about $42^{\circ} \mathrm{C} / \mathrm{W}$ for a chip bottom temperature of $80^{\circ} \mathrm{C}$. The resulting Rth for the complete power chip is $10.5^{\circ} \mathrm{C} / \mathrm{W}$, as low as the value reported in [7].

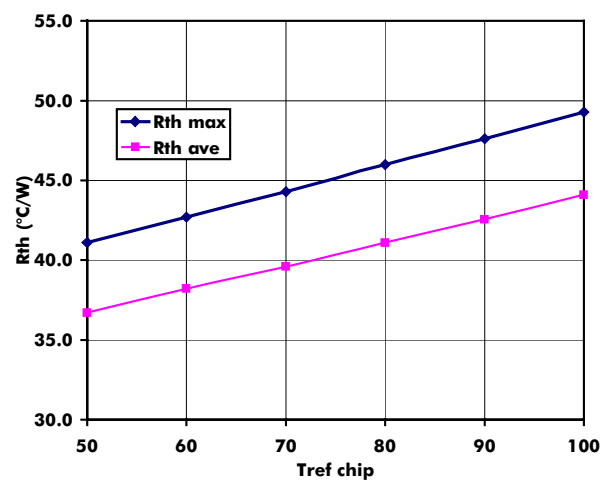

Figure 10 : Rth of an elementary cell

For the $60^{\circ} \mathrm{C}$ base plate temperature corresponding to the Galileo L Band specification temperature, the worst case junction temperature including the entire equipment packaging thermal resistance (up to calloduc) could be calculated this way :

\begin{tabular}{|c|c|c|c|c|}
\hline Signal & $\begin{array}{c}\text { Max } \\
\text { Module } \\
\text { dissipated } \\
\text { power }\end{array}$ & $\begin{array}{c}\text { Transistor } \\
\text { dissipated. } \\
\text { Power } \\
\text { (matching } \\
\text { subtracted }\end{array}$ & $\begin{array}{c}\text { Delta } \mathrm{T} \\
\text { due to } \\
\text { packaging } \\
\text { (up to } \\
\text { chip } \\
\text { bottom) }\end{array}$ & $\mathrm{Tj}$ \\
\hline $\mathrm{CW}$ & $5.8 \mathrm{~W}$ & $4.85 \mathrm{~W}$ & $22.4^{\circ} \mathrm{C}$ & $131^{\circ} \mathrm{C}$ \\
\hline 2 Tones & $4.65 \mathrm{~W}$ & $4 \mathrm{~W}$ & $18.7^{\circ} \mathrm{C}$ & $119^{\circ} \mathrm{C}$ \\
\hline
\end{tabular}

Figure 11 : Junction temperature Estimation

\section{VIII ) CONCLUSION}

The very attractive $10 \mathrm{~W} / 66 \%$ obtained thanks to high breakdown voltage HBT make them very interesting in the frame of very high power amplifier applications. To be completely compatible with a space industrial application, further improvements around the junction temperature should be engaged to reach the maximum $115^{\circ} \mathrm{C}$ for a $10 \mathrm{~W}$ output power with the real case of application signal.

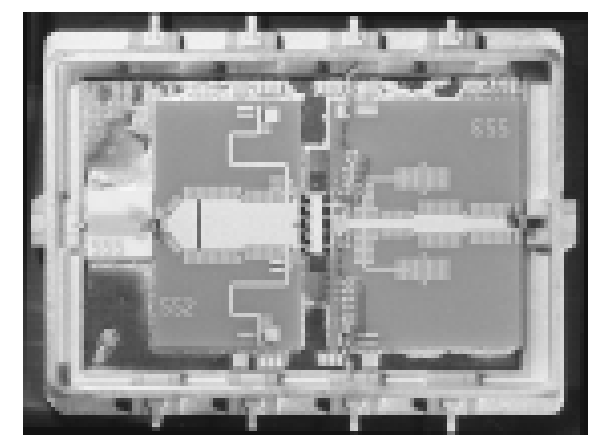

Figure 12 : Photograph of the 10W Module

\section{AKNOWLEDGMENT}

The authors would like to thank UMS (United Monolithic Semiconductors) for its helpful support to this development, and especially $\mathrm{Ph}$. Auxemery for his foundry support on HBT.

This work has been undertaken under the CNES contract 714/00/CNES/8455/00.

\section{BIBLIOGRAPHY}

[1] H. Planck, K.J. Riepe, PAuxemey, D Pons, "Industrial GaInp/GaAs Power HBT MMIC Process", GaAs 2000 conference proceedings, Paris Oct 2000, pp113-116.

[2] P. Kurpas, F. Brunner, R. Doerner, B. Janke \& Al., "High Voltage GaAs Power-HBTs for base-Station Amplifiers", Proceedings of the IEEE MTT-S, Internat. Microwave Conference 2001, Phoenix Az.

[3] J. Ph. Fraysse and al "A Non-Quasi-Static Model of GaInP/GaAs HBT for Power Applications ", IEEE MTT-S, Digest, 1997

[4] A.P. de Hek, A. de Boer and T. Svensson, "C-band 10 Watt HBT High-power Amplifier with 50\% PAE", GaAs 2001 conference proceedings, Oct 2001 Paris.

[5] J. Dubouloy, JF. Villemazet, V. Grognet, M. Soulard "Quasi 3D electromagnetic simulation with 2,5 D software" Proceedings of JNM 97 Saint-Malo, France, pp.346-347

[6] A. Darbandi, H. Buret \&Al "25 W L Band Power module for space applications", GaAs 99 conference.

[7] D. Hill, Tae S. Kim, "28-V Low Thermal Impedance HBT with 20 WCW Output Power", IEEE Trans on MTT, vol 45, no 12 Dec. 1997. 